\title{
ハイブリッドリカバリレス方式ソフトスイッチング 昇圧チョッパ回路
}

\author{
正 員 山本 真義* 学生員 戸田 浩隆* \\ 学生員 川島 崇宏* 非会員 吉田 俊幸*
}

\section{Hybrid Recovery-less Method Soft Switching Boost Chopper Circuit}

Masayoshi Yamamoto*, Member, Hirotaka Toda*, Student Member,

Takahiro Kawashima*, Student Member, Toshiyuki Yoshida*, Non-member

(2011 年 2 月 16 日受付， 2011 年 4 月 14 日再受付)

The conventional recovery-less boost type converter cannot achieve the soft switching operation in case of the turn off transition. In this paper, the novel hybrid recovery-less boost type converter, which can achieve the soft switching turn off transition, is proposed. Furthermore, the proposed hybrid recovery-less boost type converter has the switch function between the conventional recovery-less mode and the proposed soft switching mode. In general, the efficiency in the soft switching converter is less than the hard switching in case of the lower output power condition. However, using the switch function of the proposed boost type converter, the hybrid recovery-less boost type converter can achieve the high efficiency performance in the whole output power area in spite of the soft switching operation. The proposed hybrid recovery-less boost type converter is evaluated and discussed from experimental point of view.

キーワード : 昇圧チョッパ回路, リカバリレス, ソフトスイッチング

Keywords: boost chopper circuit, recovery-less, soft switching

1. はじめに

補助共振回路を付加するタイプのソフトスイッチング回 路方式において，全出力領域にて高効率を実現することは 難しい。特に低容量出力領域において, その困難性は顕著 となる。これはソフトスイッチング実現のため補助共振回 路に損失成分を補償するだけの余裕を持った電流を流す必 要があり，この電流による損失成分がソフトスイッチング による損失改善成分を上回ることに起因する。

この問題に対して筆者らは，低容量出力領域においては 補助共振回路を用いないリカバリレス動作, 大容量出力領 域においては補助回路を用いたソフトスイッチング動作へ と切り替えを行うことが可能な，ハイブリッドリカバリレ ス方式ソフトスイッチング昇圧チョッパ回路を提案してい る ${ }^{(2)}$ 。本報告では提案したソフトスイッチング昇圧チョッ パ回路について連続モード動作条件下で実機構築を行い, 効率の実測によりその切り替え機能を有する提案方式の有 効性を確認している。

\footnotetext{
*島根大学総合理工学部

干 690-8504 松江市西川津町 1060

Dept. of Interdisciplinary Faculty of Science and Engineering, Shimane University

1060, Nishikawatsu, Matsue 690-8504, Japan
}

\section{2. 提案回路}

提案するハイブリッドリカバリレス方式ソフトスイッチ ング昇圧チョッパ回路を Fig. 1 に示す。従来のリカバリレ ス昇圧チョッパ回路 ${ }^{(1)} に$ 対して, 点線部で示した補助共振 回路を付加した回路形態を構成している。昇圧用インダク タンス $L_{\mathrm{t}}$ はトランス $T$ の一次巻線の励磁成分であり, 昇 圧比に依存せずソフトスイッチングを実現するためトラン ス巻線 $n_{1}, n_{2}$ に分割される。補助インダクタンス $L_{\mathrm{a}}$ の効 果により, 主スイッチのターンオン時にはゼロ電流ターン オンが実現可能であり，同時にダイオード $\mathrm{D}_{1}, \mathrm{D}_{2}$ におい ては緩やかなソフト転流により各ダイオードにおけるリカ

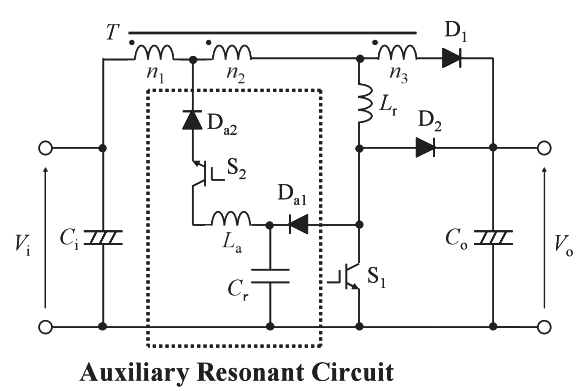

Fig. 1. Proposed hybrid recovery-less boost chopper circuit. 
Table 1. Circuit parameter of transformer-linked boost chopper circuit.

\begin{tabular}{lc|c}
\hline Input DC voltage & $V_{\mathrm{i}}$ & $100 \mathrm{~V}$ \\
\hline Output DC voltage & $V_{\mathrm{o}}$ & $230 \mathrm{~V}$ \\
\hline Switching frequency & $f_{\mathrm{s}}$ & $50 \mathrm{kHz}$ \\
\hline Boost inductor & $L_{\mathrm{t}}$ & $300 \mu \mathrm{H}$ \\
\hline Auxiliary inductor & $L_{\mathrm{a}}$ & $15 \mu \mathrm{H}$ \\
\hline Resonant inductor & $L_{\mathrm{r}}$ & $5 \mu \mathrm{H}$ \\
\hline Resonant capacitor & $C_{\mathrm{r}}$ & $56 \mathrm{nF}$ \\
\hline Number of windings & $n_{1}: n_{2}: n_{3}$ & $1: 1: 1$ \\
\hline
\end{tabular}

バリ現象を最小限に抑制可能となる。

これに対して主スイッチのターンオフ時に初めて補助共 振回路が駆動する。ターンオフ時には補助共振キャパシタ $C_{\mathrm{r}}$ がロスレススナバとして動作し, ゼロ電圧ターンオフを 実現する。さらに補助共振キャパシタ $C_{\mathrm{r}}$ に蓄積された電 荷は, 主スイッチ $\mathrm{S}_{1}$ がオンしている期間に補助スイッチ $\mathrm{S}_{2}$ を介して補助共振インダクタ $L_{\mathrm{r}}$ と補助共振キャパシタ $C_{\mathrm{r}}$ との共振現象を利用して電源側へ回生される。このとき $\mathrm{S}_{2}$ はオン, オフ時共に, 直列に接続された $L_{\mathrm{r}}$ の効果によ りゼロ電流スイッチングを実現する。しかしながら，理想 素子では考慮されないインダク夕損失, 各半導体デバイス の導通損失等により, 補助共振回路駆動時に損失を発生す る。特に低出力領域に見られる, 主回路におけるソフトス イッチング実現によるスイッチング損失の低減分を，補助 共振回路での損失が上回る条件下においては, 補助共振回 路の付加が効率向上を阻害することになる。

これに対して，提案するハイブリッドリカバリレス方式 ソフトスイッチング昇圧チョッパ回路は補助スイッチ $\mathrm{S}_{2}$ が ターンオンしない限り補助共振回路を無視することができ る。また, 補助共振回路を駆動させない状態においても, 主 スイッチにおけるターンオン, ダイオードにおけるターン オフについてはソフトスイッチング実現できており, 従来 のハードスイッチングに対して効率向上が可能となる。

\section{3. 実機動作確認}

Table 1 の回路条件の下に提案回路方式に対する実機構築 を行う。Fig. 2 に実機におけるスイッチ $\mathrm{S}_{1}$ における電圧電 流波形を示す。ここで Fig. 2(a) は提案ハイブリッドリカバ リレス方式，Fig. 2(b) は従来リカバリレス方式における実 験結果である。実験波形より原理通り動作しており，従来 方式と比較して提案方式ではターンオフにおける電圧立ち 上がりが䋧やかに抑制されており，理想的なソフトスイッ チング動作を確認できる。Fig. 3 にダイオード $\mathrm{D}_{1}$ における 電圧電流波形を示す。この図より提案方式においてスイッ チ $\mathrm{S}_{1}$ におけるソフトスイッチングターンオフを実現しな がらも, 従来方式と同等のリカバリレス動作が実現できて いる。

Fig. 4 に効率測定結果を示す。 $700 \mathrm{~W}$ 以下の低出力領域 において, 提案方式では前述の理由により, 補助共振回路 を駆動させることで従来のリカバリレス方式と比較して効 率の低下が見られる。しかしながら, 出力が増大していく (a) Hybrid recovery-less method

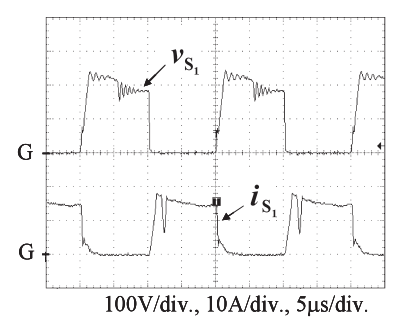

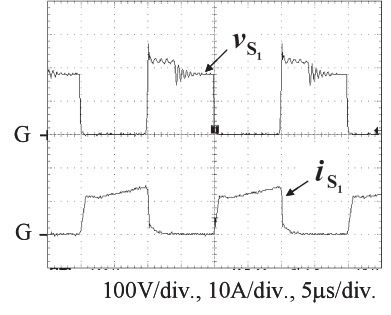

(b) Conventional method
Fig. 2. Voltage and current waveforms in switch $S_{1}$.

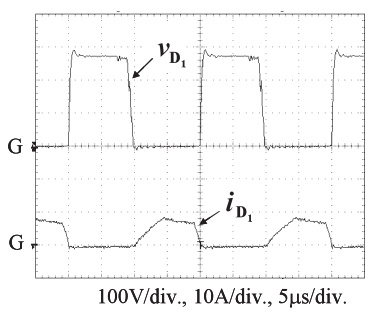

(a) Hybrid recovery-less method

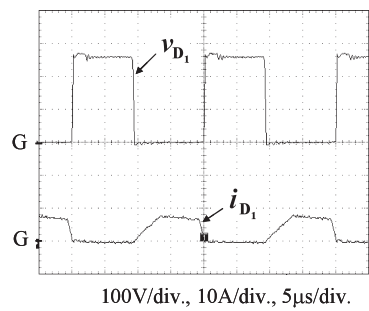

(b) Conventional method
Fig. 3. Voltage and current waveforms in diode $\mathrm{D}_{1}$.

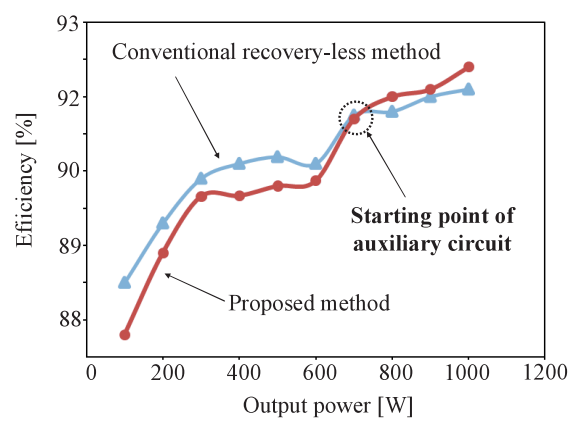

Fig. 4. Comparative data of efficiency.

に従いソフトスイッチング効果が効率に対して大きくなり， 提案方式における効率は従来方式と比較して向上する。提 案方式と従来方式の効率が一致する $700 \mathrm{~W}$ 時点で提案方式 において補助共振回路の駆動を開始すれば，全領域におけ る効率向上が見込める。

4. まとめ

全出力領域において効率向上が可能なハイブリッドリカ バリレス方式ソフトスイッチング昇圧チョッパ回路を提案 し，実機動作確認を行った。さらに効率測定結果より，全 出力領域における提案回路の効率向上性能を示唆した。

\section{文献}

(1) T. Kawashima, S. Funabiki, M. Yamamoto, M. Tsuruya, and M. Ochiai: "Recovery-less Boost Converter for Electric Vehicle", Journal of the Japan Institute of Power Electronics, Vol.33, pp.107-114 (2008) (in Japanese) 川島崇宏・船曳繁之・山本真義・鶴谷 守·落合政司：「電気自動車 用昇圧コンバータのリカバリレス化」, パワーエレクトロニクス学会 誌, Vol.33, pp.107-114 (2008)

(2) T. Toda, T. Kawashima, and M. Yamamoto: "Hybrid Recovery-less Method Soft Switching Boost Chopper Circuit", The 2010 Annual Meeting Record of IEEJ, No.1, pp.355-356 (2010) (in Japanese)

戸田浩隆・川島崇宏・山本真義：「ハイブリッドリカバリレス方式ソ フトスイッチング昇圧チョッパ回路」, 平成 22 電気学会産業応用部 門大会, No.1, pp.355-356 (2010) 